\title{
DIETARY PATTERNS IN STREAM- AND LAKE-DWELLING POPULATIONS OF AUSTROPOTAMOBIUS PALLIPES
}

\author{
REYNOLDS, J.D. (1), O'KEEFFE, C. (2)
}
(1) Department of Zoology, University of Dublin, Trinity College, Dublin 2, Ireland. E-Mail: jrynolds@tcd.ie
(2) National Parks and Wildlife Service, 7 Ely Place, Dublin 2, Ireland.

Reçu le 4 novembre 2004

Accepté le 17 décembre 2004

Received November 4, 2004

Accepted December 17, 2004

\begin{abstract}
White-clawed crayfish (Austropotamobius pallipes) are widespread in Ireland in both running and standing water, although stream-dwelling in much of their range elsewhere. A detailed comparative study of a lake and a stream population demonstrated that diets changed with crayfish size from feeding on entomostracans to a predominance of aquatic macrophytes and terrestrial vegetation. However, carnivory remained important at all sizes: Gammarids were a significant component in larger lake crayfish and in all sizes of stream crayfish. Fish increased in importance with crayfish size. A. pallipes thus appears more carnivorous than some other European and American crayfish. The extent to which this is related to habitat is discussed.
\end{abstract}

Key-words: Austropotamobius pallipes, diet, lake, stream, carnivory.

\section{COMPARAISON DES RÉGIMES ALIMENTAIRES DES POPULATIONS LACUSTRES ET DES RIVIĖRES DES ÉCREVISSES À PATTE BLANCHE AUSTROPOTAMOBIUS PALLIPES}

\section{RÉSUMÉ}

L'écrevisse à patte blanche (Austropotamobius pallipes) est largement répandue en Irlande dans les rivières comme dans les plans d'eau, bien qu'ailleurs, sur la majeure partie de leur aire de distribution, elle n'habite que les rivières. Une étude comparée et détaillée d'une population de ruisseau et d'une population lacustre a démontré que l'alimentation change selon la taille avec une prédominance des entomostracés chez les plus petits individus jusqu'à celle des macrophytes et de la végétation terrestre chez les plus gros. Néanmoins, la composante animale du régime alimentaire reste importante à toutes les tailles. Les gammaridés sont consommés en milieu lacustre par les écrevisses les plus grosses et par les écrevisses de ruisseau de toute taille. La consommation de poissons augmente avec la taille des écrevisses. II apparaît qu'Austropotamobius pallipes est plus carnivore que plusieurs autres écrevisses d'Europe ou d'Amérique du Nord. Le degré auquel ce régime alimentaire est relié à l'habitat est discuté.

Mots-clés : Austropotamobius pallipes, alimentation, lac, ruisseau, carnivore. 


\section{INTRODUCTION}

The Irish populations of white-clawed crayfish Austropotamobius pallipes (Lereboullet) are now thought to be unique in Europe (REYNOLDS, 1997; REYNOLDS, DEMERS and MARNELL, 2002). Irish stocks share a very uniform genetic structure, apparently concordant with introduction from Western France (REYNOLDS et al., 2002; GOUIN et al., 2003). However, they also show the widest expression of habitat occupancy for this species, being widespread in rivers, streams and small lakes (REYNOLDS, 1979; LUCEY and McGARRIGLE, 1987; REYNOLDS, DEMERS and MARNELL 2002). This may be related to their presumed introduction, to a lack of competition from other decapods, and to the relative infrequency of outbreaks of crayfish plague (REYNOLDS, 1988, 1997) which has restricted this species to headwaters in much of its range elsewhere. It is likely that other aspects of the fundamental niche, such as diet, may be equally broadly expressed among Irish white-clawed crayfish. Knowledge of its fullest potential is important when planning the conservation of this internationally protected species (HOLDICH and ROGERS, 1997).

There have been several approaches to understanding the diet of white-clawed crayfish. Studies have been observational (e.g. HUXLEY, 1880; ANDRÉ, 1960), experimental tests of food choice (e.g. THOMAS, 1977, 1979; REYNOLDS, 1979; REYNOLDS and DONOHOE, 2001) or stomach analyses (e.g. O'KEEFFE, 1986). Comparable studies are available for a range of other crayfish species (see, for example, NYSTRÖM $(1999,2002)$ and, for Austropotamobius torrentium, RENZ and BREITHAUPT (2000)). The present study, for which fieldwork was carried out in 1979-1981 (O'KEEFFE, 1986), is the first to provide baseline comparative information on diets of white-clawed crayfish of different sizes in a stream and a lake situation.

\section{MATERIAL AND METHODS}

\section{Description of sites}

Both study sites lie in east-central Ireland. White Lake, Counties Meath and Westmeath, $80 \mathrm{~km} \mathrm{NW}$ of Dublin (National Grid Reference N57) (Shannon and Boyne catchments; Figure 1) is a high alkalinity marl lake lying on glacially derived gravels overlying Upper Carboniferous limestone, at an altitude of $107 \mathrm{~m}$. The lake is 32 ha in area and $15 \mathrm{~m}$ deep, in a catchment of $252 \mathrm{ha}$, landlocked between the Shannon and Boyne catchments, and with a subterranean outlet. Water levels vary by about $3 \mathrm{~m}$ each year, reaching a maximum in December and dropping from June onwards. There is a shallow littoral mostly of fine marly mud and patchy Chara, but gravels occur in parts of the shoreline.

White Lake, now a candidate SAC for crayfish under the Habitats Directive, was formerly one of the country's best known crayfish sites. It lost its crayfish stocks in around 1986, believed to have been as a result of a crayfish plague outbreak (REYNOLDS, 1988; MATTHEWS and REYNOLDS, 1992). However, crayfish have since been reintroduced to this site by the National Parks and Wildlife Service (REYNOLDS et al., 2000; REYNOLDS, DEMERS and MARNELL, 2002) and breeding was confirmed in 2003.

While many Irish headwater streams are acidic because of the underlying igneous or metamorphic geology, some flow either over carboniferous limestone or over calcareous glacial till. Lisheens stream, Co. Wicklow (National Grid Reference O02) (Liffey catchment; Figure 1) is such a stream, its granitic catchment overlain by glacial drift of Carboniferous origin. It was sampled at approximately 2,900-3,000 m downstream of its source, at an altitude of $215 \mathrm{~m}$. At this site the stream averaged $1.5 \mathrm{~m}$ in width and $0.7 \mathrm{~m}$ deep under normal conditions, with flow rates of 0.8 to $1.5 \mathrm{~m} \mathrm{sec}^{-1}$. 


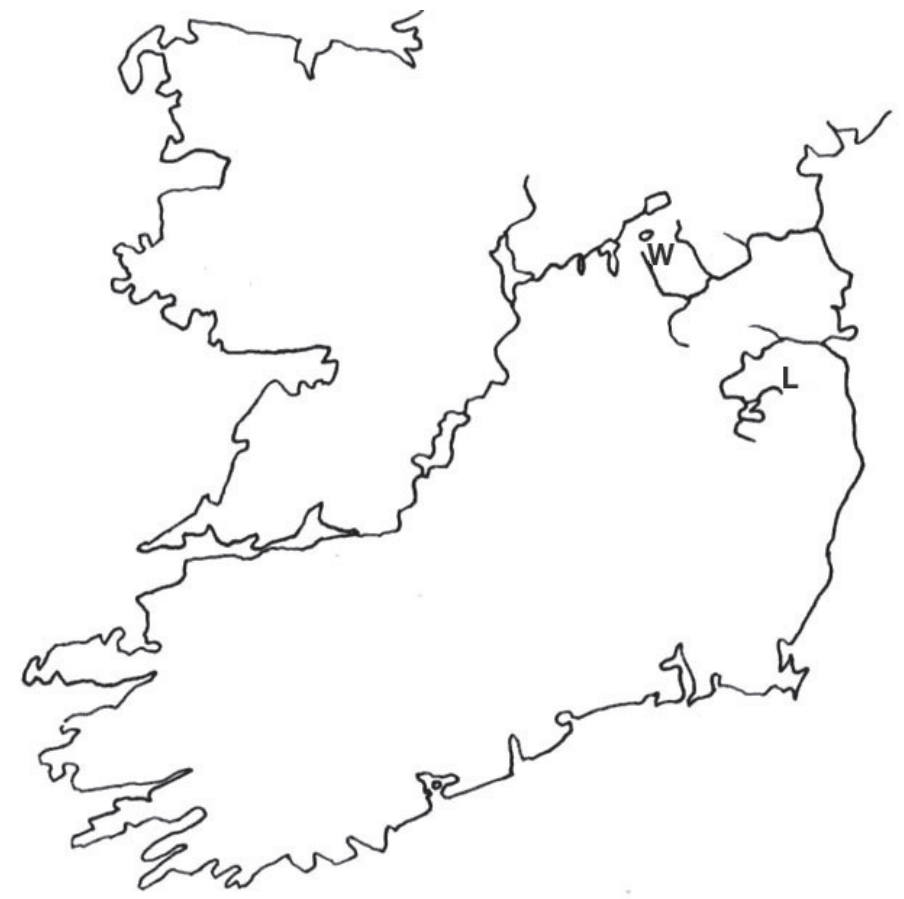

Figure 1

Map of southern Ireland, showing the study sites. W: White Lake; L: Lisheens stream.

\section{Figure 1}

Carte du sud de I'Irlande, montrant les différents sites étudiés: W: Lac White; L: Fleuve Lisheens.

\section{Environmental parameters}

Water temperatures were measured using submersible Peabody Ryan thermographs, while conductivity, $\mathrm{pH}$ and hardness were measured with WTW electronic probes. In summer 1979 the lake was always $1.5^{\circ} \mathrm{C}$ to $5.0^{\circ} \mathrm{C}$ higher than the stream, with maxima of $20^{\circ} \mathrm{C}$ and $17^{\circ} \mathrm{C}$ respectively. Stream temperatures fluctuated diurnally up to $7.0^{\circ} \mathrm{C}$, whereas lake temperature at $3 \mathrm{~m}$ depth varied little over $24 \mathrm{hrs}$, the range rarely exceeding $1^{\circ} \mathrm{C}$. In July 1981 conductivity averaged $260 \mu \mathrm{S} \mathrm{cm}^{-1}$ in White Lake, $80 \mu \mathrm{S} \mathrm{cm}^{-1}$ in Lisheens. pH was 8.6 at White Lake, 7.6 in Lisheens Stream, while hardness was $217 \mathrm{ppm} \mathrm{CaCO}_{3}$ in White Lake, 44 in Lisheens.

\section{Crayfish collections and processing}

Crayfish were collected for stomach analyses between October 1979 and July 1981. White Lake samples were taken in pond nets or were caught by SCUBA divers. In Lisheens Stream hand nets and night capture were used, to ensure a complete range of sizes. All collections made during daylight were completed by noon. Specimens were wrapped in plastic and frozen in liquid nitrogen. In the laboratory specimens were thawed and sex, weight and carapace length were recorded for each crayfish; following dissection reproductive state, stage of moult cycle and signs of disease were further noted. The gastric mill was removed and weighed, then its contents washed out and fullness with solids rated on a 0 (empty) to 5 (full) scale.

The mostly fragmented stomach contents were then separated as far as possible into distinct food types, and the composition of each food type visually estimated as a 
percentage of the total volume of the sample. Preserved samples were then stored for several months before a second analysis to minimise bias. Dry weights were recorded after $24 \mathrm{~h}$ drying at $90^{\circ} \mathrm{C}$.

\section{Data analysis}

Three different forms of numerical analysis were used, but only volume scores and percentage occurrence are considered in this paper.

(1) Volume score (VS) was calculated by multiplying the fullness score of a stomach by the percentage volume of that category of foodstuff in the contents. This is a modification of HYNES' (1959) method.

(2) Dry weight score (DWS) was calculated by multiplying the total dry weight of the contents of a stomach by the percentage volume of a food category in the stomach. While this method is not truly gravimetric, it removes one element of subjectivity and allows comparison of the quantities of food eaten by different sizes of crayfish.

(3) Percentage occurrence: the proportion of stomachs in which a food category occurred.

Finally, digestion rates were examined for 61 White Lake crayfish (24 sub-yearlings 6-7 $\mathrm{mm} \mathrm{CL}$ and 37 adults of CL 25-57 mm), collected between 0100 and $0200 \mathrm{~h}$ on 29 July 1981 . Six of each size were killed and frozen immediately; the rest were held at $15^{\circ} \mathrm{C}$ without food and sacrificed at 3-hourly intervals to check food retention, for up to $84 \mathrm{~h}$ after collection.

\section{RESULTS}

A total of 388 crayfish stomachs were examined; 254 from White Lake and 134 from Lisheens Stream. 40 food items or groups identified in crayfish stomachs are listed in Table 1. Six of these (Chara, microcrustacean groups apart from ostracods, Asellus and Bryozoans) were found only in lake crayfish.

In tests, food retention times at $15^{\circ} \mathrm{C}$ increased with crayfish size. In sub-yearlings (6-7 mm CL) all food was digested within 11 hours, whereas adults retained many food items for more than $15 \mathrm{hr}$, and plant fragments were detectable for over $72 \mathrm{hr}$.

Stomach contents were analysed separately by size class (Table 2, Figures 2, 3). Four size classes were recognised in White Lake $(\mathrm{CL}<12 \mathrm{~mm}, 12-26 \mathrm{~mm}, 27-39 \mathrm{~mm}$ $>40 \mathrm{~mm}$ ) but five in Lisheens Stream, necessitated by the slower growth rate of subyearlings (up to $8 \mathrm{~mm} \mathrm{CL}$ ) in the stream than in the lake.

Certain food items occurred in a high percentage of crayfish, notably plant fragments in all but the smallest crayfish, microcrustaceans in the smallest lake crayfish, Chara and molluscs in the largest lake crayfish and Diptera and fish in the largest size-category in both lake and stream (Table 2). Other items, e.g. worms and bryozoans, figured in only a small percentage of individuals.

At both sites, crayfish diet changed with size from a predominance of animal food to predominantly plant (Table 2). In White Lake, total plant matter occurred to a greater proportion in larger than smaller crayfish, rising from $24.5 \%$ to $81.4 \%$ in the largest sizeclass. Animal matter was important to all sizes of crayfish, occurring in $73 \%$ to $92.5 \%$, but there was no overall trend with size. In Lisheens stream, animal matter similarly occurred in $76 \%$ to $100 \%$ of crayfish of all size classes. Plant matter occurred in $37 \%$ of the smallest stream sub-yearlings, rising to around $90 \%$ in the $12-26 \mathrm{~mm}$ size-class.

Crustaceans occurred in about half of the smallest White Lake crayfish, falling off to around $30 \%$ in the largest group (Table 2). In Lisheens stream ostracods were only 


\section{Table I}

Food items found in stomachs of white-clawed crayfish from White Lake and Lisheens Stream, Ireland. "L" and "S" indicate items restricted to lake and stream, respectively.

\section{Tableau I}

Aliments trouvés dans des estomacs d'écrevisses à pattes blanches du lac White et du fleuve Lisheens, Irlande. " $L$ " et " $S$ " désignent les éléments trouvés respectivement uniquement dans le lac ou dans le fleuve.

Woody plant fragments

Green plant (filamentous algae, Fontinalis sp., Gramineae)

Tree leaf, seed

Charales (L)

Nematoda

Nematomorpha (Gordius sp.)

Turbellaria

Annelida Oligochaeta

Hirudinea (Erpobdella octoculata)

Crustacea Ostracoda

Chydoridae (Alona quadrangularis) (L)

Other Cladocera (Daphnia longispina, Sida crystallina) (L)

Copepoda Calanoida (L)

Amphipoda (Gammarus lacustris, G. duebeni)

Isopoda (Asellus aquaticus) (L)

Decapoda (Austropotamobius pallipes)

Ephemeroptera larvae (Caenis moesta, Centroptilum luteolum)

Plecoptera larvae

Coleoptera larvae

Trichoptera larvae

Diptera larvae (Chironomidae, Tipulidae, Ceratopogonidae)

Other insecta (Cicadellidae)

Mollusca Bivalvia (Sphaerium sp.)

Gastropoda (Bithynia tentaculata, Valvata sp., Planorbis sp., Potamopyrgus jenkinsi)

Bryozoa (statoblasts of Cristatella sp., Plumatella sp.). (L)

Fish (Rainbow trout Oncorhynchus mykiss, nine-spine stickleback Pungitius pungitius)

Eggs

important in crayfish less than $12 \mathrm{~mm}$ in carapace length, and gammarids occurred in all the smaller size-classes. Molluscs were absent in sub-yearlings at both sites, and rose to about $34 \%$ in large crayfish. By contrast, larval and adult insects occurred in 20 to $50 \%$ of all Lisheens crayfish, and in $17.6 \%$ to $24.3 \%$ of those in White Lake, showing no apparent trends with size. Fish were only important to the largest size category.

A picture of the relative importance of food items is given in the percentage volume scores (Figures 2, 3). Plant matter made up around $40 \%$ of the food by volume in the larger crayfish, while crustaceans and insects formed over $50 \%$ of the diet of the smallest lake and stream crayfish respectively. Microcrustaceans were only important to the smallest size classes at each site, while in the stream, gammarids were also important from earliest stages (Figure 3).

Diets of 15 soft-shelled crayfish were studied from both sites. Less than $60 \%$ of soft crayfish examined contained food, compared to over $80 \%$ in the general population; all but one in pre-moult were empty. Around one third of the diet by volume was made 


\section{Table II}

Percentage occurrence of food items in different size classes of white-clawed crayfish at White Lake and Lisheens Stream, Ireland.

Tableau II

Sortes d'aliments, en pourcentage, trouvés chez les différentes classes de tailles d'écrevisses à pattes blanches du lac White et du fleuve Lisheens, Irlande.

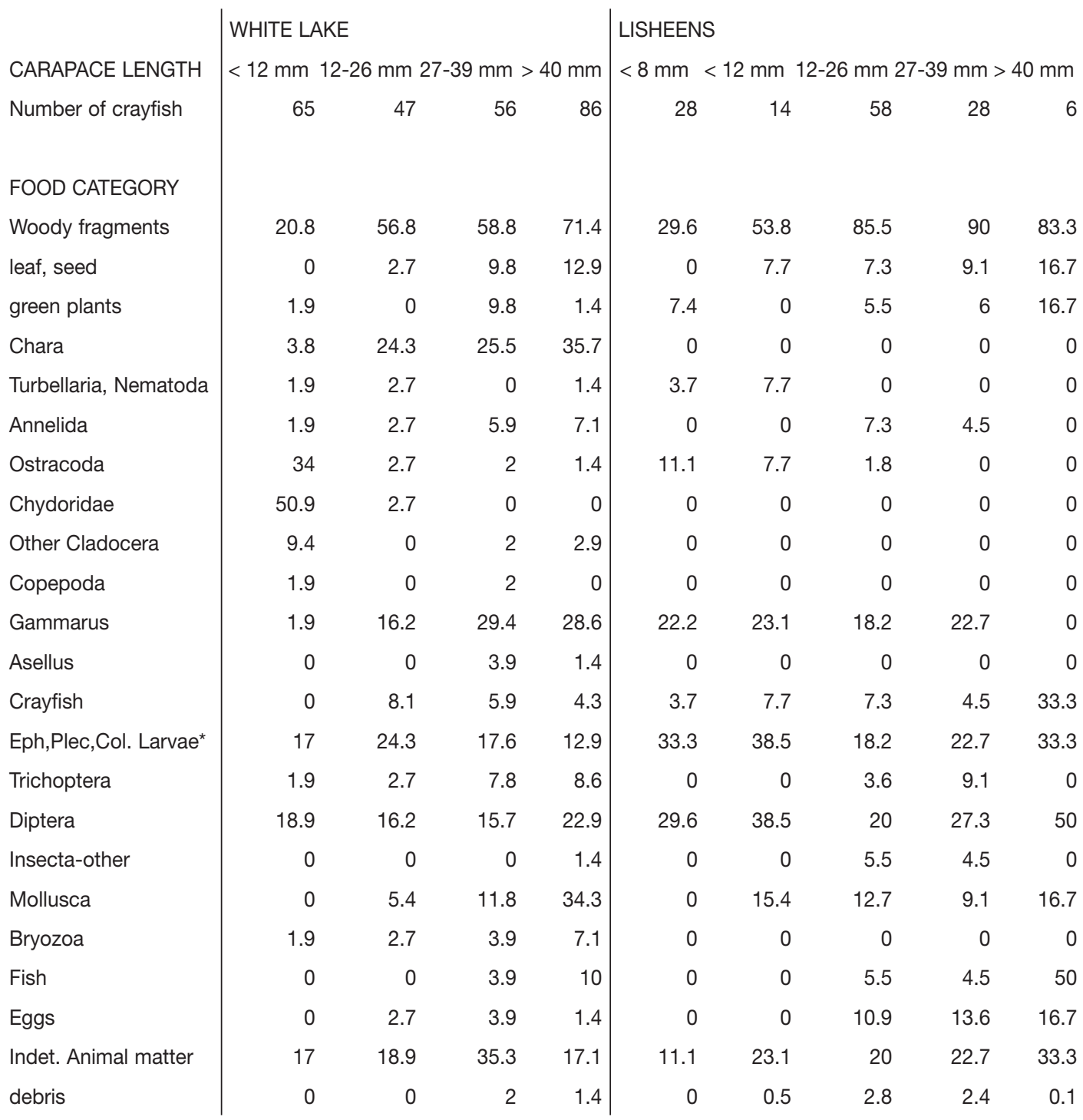

* Larvae of Ephemeroptera, Plecoptera, Coleoptera.

up of plant material in the stream and lake respectively (Figure 4). Crayfish shell was a characteristic feature in stomach contents of soft crayfish, making up more than twice as much by volume in Lisheens stream as In White Lake.

The diet of twelve lake-caught ovigerous females indicated a similar fullness to that of mature, non-berried lake females, around $83 \%$ of each group containing food (Figure 5). However, more plant leaf material matter was taken by the ovigerous females than by the general population in that size class, and less Chara. Among animal food, berried females took fewer crustaceans, insects and fish, but more molluscs. 


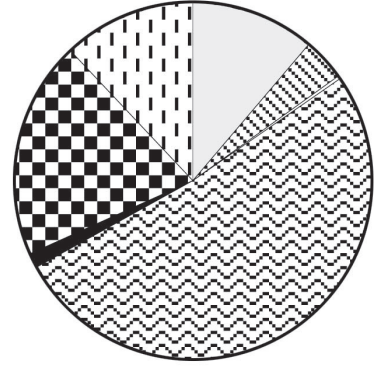

A

$\mathrm{n}=65$

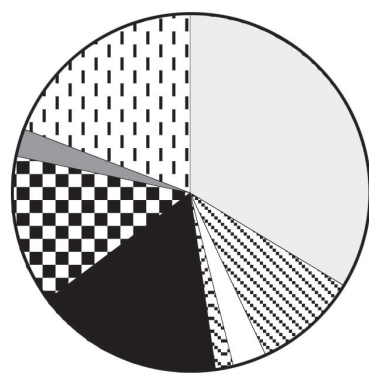

C

$\mathrm{n}=56$

Leqend

:. Plant matter

\ Chara

Worms

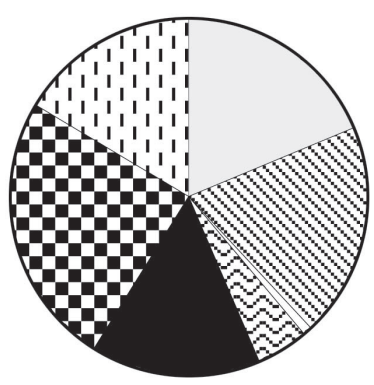

B

$\mathrm{n}=47$

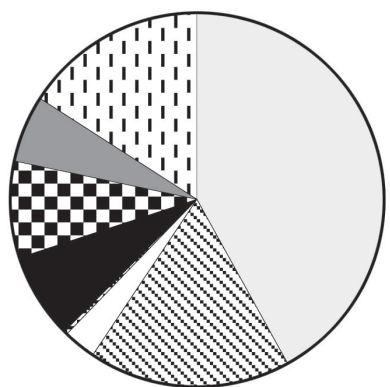

D

$\mathrm{n}=86$

$\checkmark$ Microcrustaceans

$\square$ Fish

Macrocrustaceans

D. Other animal matter

B Insects

\section{Figure 2}

Percentage volume of food items in crayfish stomachs in White lake. A: $C L$ < 12 mm; B: CL 12-26 mm; C: 27-39 mm; D: CL > 40 mm.

\section{Figure 2}

Volume, en pourcentage, de différentes sortes d'aliments trouvés dans les estomacs d'écrevisses du lac White, pour différentes classes de taille d'aliment. A: $C L$ < 12 mm; B: CL 12-26 mm; C: 27-39 mm; D: CL > 40 mm.

\section{DISCUSSION}

The rate of digestion of food was more rapid in small than in large crayfish. Much of the adults' food remained in the stomach complex for more than 15 hours, with refractory plant fragments retained for more than 3 days. Although diets were shown to change with size, this could also have the effect of increasing the apparent importance by volume of plant matter as food.

Feeding comparisons between lake and stream at different sizes must also take into account the different macroinvertebrate and plant communities in each habitat. For example, Chara occurred only in the lake, where it was a component of the diet in all size classes. Among microcrustaceans, the stream had only ostracods, while the lake had various crustacean zooplankters. The lake held both Asellus and Gammarus, but only 

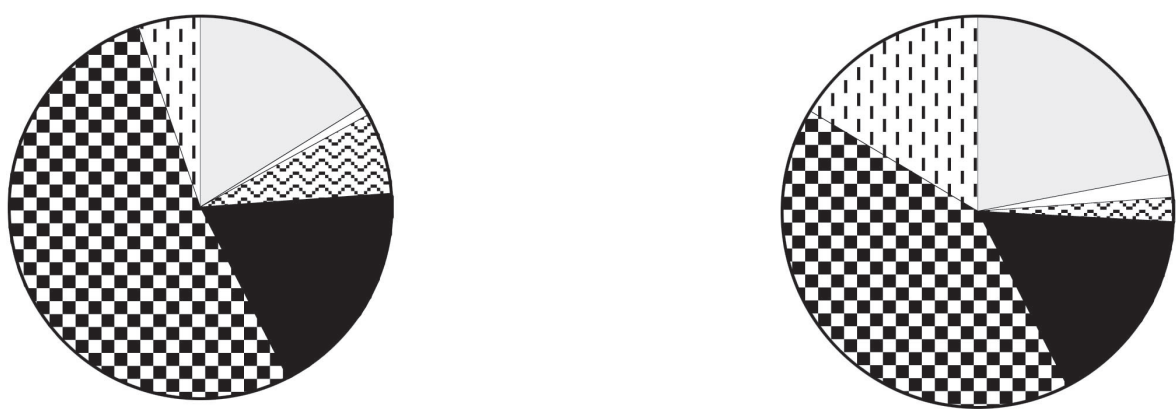

$A$
$n=28$

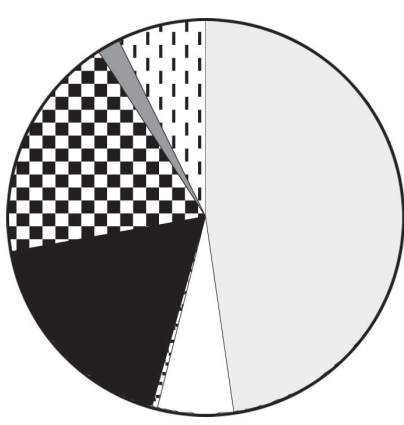

B

$\mathrm{n}=14$

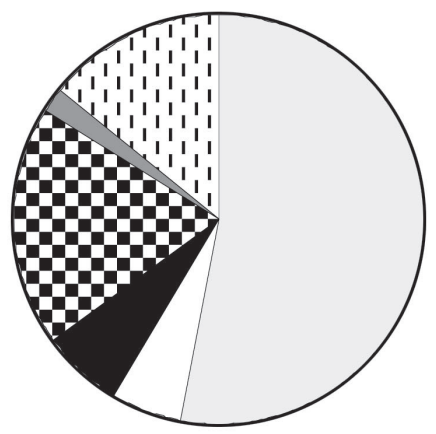

D

$n=28$

C

$\mathrm{n}=58$

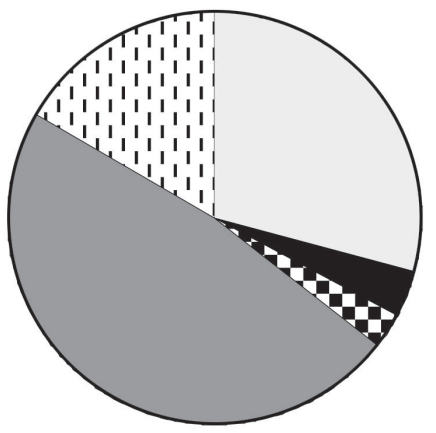

E

$\mathrm{n}=6$

Leqend

:8 Plant matter

S Chara

Worms
Microcrustaceans

Macrocrustaceans

$\mathbf{Q}$ Insects

\section{Figure 3}

Percentage volume of food items in crayfish stomachs in Lisheens Stream. A: CL < 8 mm; B: CL 8-12 mm; C: CL 12-26 mm; D: 27-39 mm; E: CL > 40 mm.

\section{Figure 3}

Volume, en pourcentage, de différentes sortes d'aliments trouvés dans les estomacs d'écrevisses capturés dans le fleuve Lisheens, pour différentes classes de taille d'aliment. A: CL < $8 \mathrm{~mm}$; B: CL 8-12 mm; C: CL 12-26 mm; D: 27-39 mm; E: $\mathrm{CL}>40 \mathrm{~mm}$. 


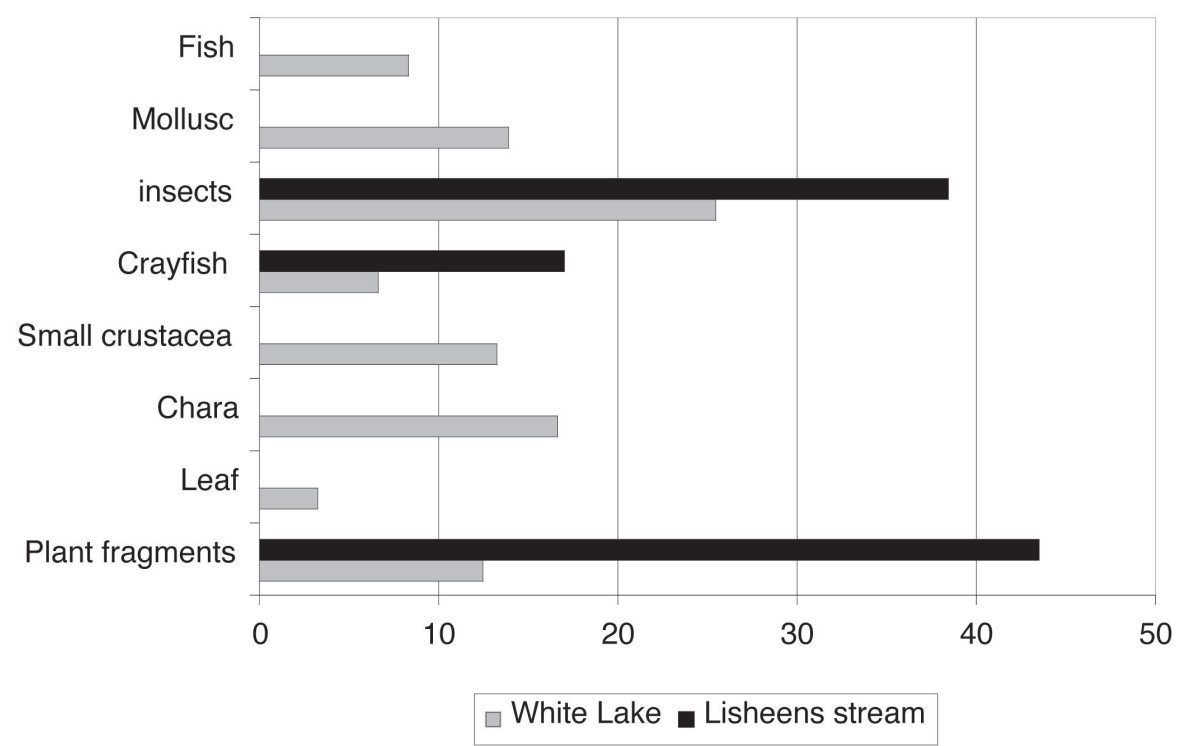

Figure 4

Percentage volume of food items in stomach contents of soft-shelled crayfish from Lisheens Stream and White Lake, Ireland.

\section{Figure 4}

Volume, en pourcentage, de différentes sortes d'aliments trouvés dans les contenus stomacaux d'écrevisses capturées dans le fleuve Lisheens et dans le lac White, Irlande.

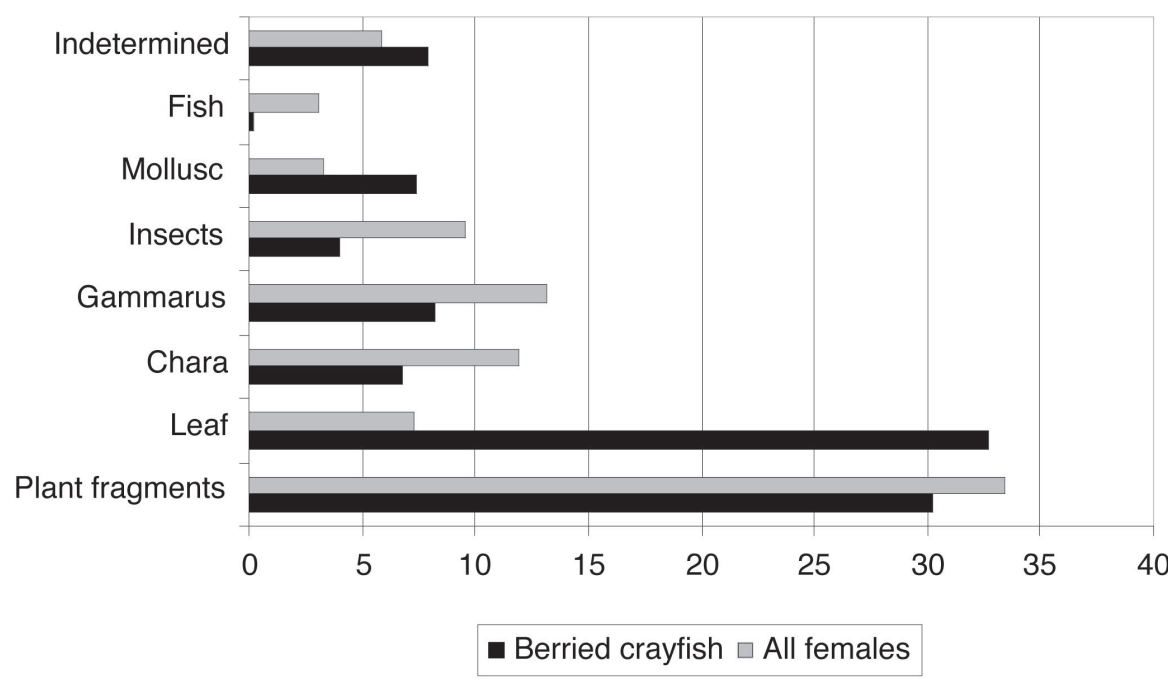

Figure 5

Percentage volume of food items in stomach contents of berried females and all mature females (CL > $27 \mathrm{~mm}$ ) in White lake, Ireland.

Figure 5

Volume, en pourcentage, de différentes sortes d'aliments trouvés dans les estomacs d'écrevisses femelles porteuses d'œufs et de toutes les femelles mâtures (CL > $27 \mathrm{~mm}$ ) capturées dans le lac White, Irlande. 
the latter occurred in the stream. However, in general lake crayfish fed more heavily on gammarids than did those in the stream.

Crayfish at both study sites began life as predominantly carnivorous, but gradually changed to a diet containing more plant than animal matter. The change was effected through an increase in the occurrence and amount of plant food with crayfish size. Thus, occurrence of plant items in lake crayfish rose from $24.5 \%$ in the $0+$ size class to $91.4 \%$ in the largest size-class, while the corresponding decrease in occurrence of animal matter was only from $92.5 \%$ to $82.9 \%$.

The change appeared to be a function of crayfish size rather than age. Annual growth increments were lower in the stream than in the lake (O'KEEFFE, 1986). This is related to the degree and duration of high summer temperatures, and as a consequence stream crayfish moulted later and more rarely attained a large size than in the lake. Stream $0+$ juveniles were also smaller than those in the lake (O'KEEFFE, 1986). In White Lake the $1+$ crayfish are much larger than the $0+$ and differ markedly in diet (Figure 2), whereas the size difference is much smaller in the stream, and the diets more closely similar (Figure 3).

When feeding on animals, Austropotamobius pallipes displays an inverse relationship between its size and the proportion of mobile animals in its diet. Small, mobile items such as water fleas and very small insects were important only in the diet of sub-yearling crayfish. The abrupt switch in dependence of White Lake crayfish above $12 \mathrm{~mm} \mathrm{CL}$ from dependence on microcrustaceans to other organisms is probably because the change is energetically more profitable. Larger, more mobile forms such as insect larvae and gammarids were important in 12-40 mm crayfish but of relatively little significance in the largest animals. This change may be attributed to loss of feeding dexterity with increasing size; THOMAS (1977) has shown that chela setation changes with size, making the chela less suitable for prehension. It would appear, therefore, that older animals are forced through clumsiness to feed mostly on plant matter, but they will take animal food whenever the opportunity arises, as in the laboratory. Such ontogenetic shifts are well known for other crayfish (e.g. LODGE and HILL, 1994; MOMOT, 1995).

Soft white-clawed crayfish from both stream and lake contained less food than the overall sample. Premoult crayfish were almost always empty, while most post-moult soft crayfish contained crayfish shell material, particularly those from the stream. Lisheens stream has one-fifth the calcium concentration of that found in lake waters, and there may be a correspondingly greater need for stream crayfish to recycle calcium from their exuviae.

Ovigerous female crayfish stomachs were of similar mean fullness to that of non-berried females. However, relatively more plant matter was taken by the ovigerous females. Fish were almost never eaten and insect larvae were notably scarce, suggesting either a more limited mobility when berried, or perhaps a behavioural feeding inhibition in reaction to these small, motile prey.

The patterns of feeding behaviour displayed by Irish white-clawed crayfish may be compared with those described for other species. The feeding of young stream whiteclawed crayfish is comparable with that observed for Pacifastacus leniusculus in Oregon streams, which fed first on insect larvae but consumed more plant material as they grew larger (MASON, 1975). However, lake and stream white-clawed crayfish were found to be more carnivorous than most other species. For example, large White Lake crayfish of CL $40+\mathrm{mm}$ contained $40 \%$ by volume of animal food. In contrast, MASON (1975) found that Pacifastacus of a similar size $(T L 80+\mathrm{mm}$ ) ate less than $20 \%$ animal food, while HESSEN and SKURDAL $(1986,1988)$ reported a figure of about $14 \%$ for Astacus astacus of $45 \mathrm{~mm} \mathrm{CL}$ and above. Sub-yearlings of $A$. pallipes at both White Lake and Lisheens 
consumed some $80-85 \%$ animal matter, compared with $65 \%$ in Pacifastacus (MASON, 1975). In White Lake, plant matter occurred in only $25 \%$ of sub-yearlings, whereas WESTMAN et al. (1986) reported $40 \%$ in A. astacus summerlings in Finnish rivers and MOMOT, GOWING and JONES (1978) noted 100\% plant occurrence in Orconectes virilis of the same age.

Larger Orconectes propinquus ate Chara over other available macrophytes. Fresh macrophytes were not important, but periphyton, plant detritus and invertebrates especially so. Arthropods were detected in nearly $80 \%$ of all stomachs. By contrast, volume of plant detritus reached a September maximum of about 15\% (SAFFRAN and BARTON 1993).

Reasons for these differences between species and sites are not clear. Obviously there are discrepancies between food types available at different sites, as between White Lake and Lisheens stream, yet the absolute amounts of plant and animal food in the diets at both these sites seems higher than in many other crayfish species. In a related species, Austropotamobius torrentium, feeding tests showed increased proportions and a wider variety of animal food in the diet at summer $\left(14^{\circ} \mathrm{C}\right)$ than spring $\left(7^{\circ} \mathrm{C}\right)$ temperatures (RENZ and BREITHAUPT, 2000).

Many crayfish appear to filter feed on plankton as juveniles. Young Orconectes virilis would appear to filter-feed, as pine pollen and diatoms formed an important part of their diet in Michigan (MOMOT, GOWING and JONES, 1978), while diatoms were also seasonally important for O. propinquus (SAFFRAN and BARTON, 1993). THOMAS (1979) considered that filter-feeding was the dominant mode of food collection in second to fourth stage hatchlings of $A$. pallipes, but the results here indicate that young crayfish may feed by catching rather than by filtering. Sub-yearlings of Astacus leptodactylus cubanicus in ponds fed on Daphnia and chironomid larvae but during their first summer they switched to other insect larvae and then to gammarids (TCHERKASHINA, 1977). However, stream sub-yearlings of this species fed on gammarids from their earliest days. Both these trends are similar to those displayed by $A$. pallipes in Ireland, but spread over the first two summers. White Lake crayfish of all sizes, but especially the larger ones, were found to have ingested bryozoan statoblasts (0.1-0.3 mm diameter). Even adult white-clawed crayfish can filter-feed opportunistically (THOMAS, 1979), but it is most likely that these items were ingested accidentally when the crayfish fed on plant matter, given their relative scarcity in the environment, and the inability of large crayfish to manipulate tiny objects

Several prey categories of $A$. pallipes were of particular interest. The size and agility of most fish must render them immune to crayfish predation, however, the occurrence of the stickleback Pungitius in stomachs of crayfish other than berried females shows that small fish may be at risk. Sticklebacks are commonly found in Chara beds and may thus be accessible to crayfish. While the angling intensity in White Lake may provide additional crayfish food in the form of discarded fish, there is no angling in Lisheens stream, yet three of the six largest crayfish contained fish, which it is most likely that they attacked and killed. In captivity, the related Austropotamobius torrentium originating from both streams and from Lake Constance also captured and ate sticklebacks (RENZ and BREITHAUPT, 2000). In Britain, the introduced Pacifastacus leniusculus was seen to consume bullhead and stone loach in captivity, and in the wild high concentrations of signal crayfish were associated with declines in fish, attributable in part to competition for shelter (GUAM and WILES, 1997). By contrast, WESTMAN et al. (1986) reported that Astacus astacus was not a fish predator in Finnish rivers, and HESSEN and SKURDAL (1986) only found Coregonus remains in $A$. astacus guts when these fish were used to bait crayfish traps. In Swedish river enclosure experiments trout fingerlings were unaffected by Pacifastacus leniusculus.

The evidence of $A$. pallipes predation on molluscs was often unidentifiable fragments of shell, as in more than half of the occurrences in lake crayfish and almost one third of those in the stream. Up to one third of the largest lake crayfish contained molluscs. In the 
stream, snails occurred in over $15 \%$ of the yearlings $(1+, \mathrm{CL} 9-11 \mathrm{~mm})$, probably related to the small size of the most common gastropod species Potamopyrgus jenkinsi. In other crayfish dietary studies, WARNER (1997) discussed the factors affecting selection of different sized snails by P. leniusculus, while ILHEU and BERNARDO (1993) showed that Procambarus clarkii preferred snails over insect nymphs.

Certain insect groups common in the lake shallows were not found in crayfish stomachs. Larval zygopterans e.g. Enallagma sp. and water scorpions Nepa cinerea were plentiful but not eaten, however, ANDRÉ (1960) lists both in the diet of French crayfish. NYSTRÖM (2002) found some selection of odonatans by juveniles in $P$. leniusculus.

Certain other possible foodstuffs were, however, also absent from or rare in the studied crayfish. The absence of aquatic phanerogams from the diets of wild-caught crayfish is notable. The only aquatic macrophyte found regularly in the food was Chara, which occurred only in the lake. There were large stands of watercress (Nasturtium sp.) in the stream, harbouring many invertebrates, yet crayfish were rarely found within these and watercress was not seen to form part of the diet. In feeding trials REYNOLDS (1979) also found that aquatic vegetation was the least favoured among nine food categories offered.

However, many other crayfish species are recorded as grazing on macrophytes. GAEVSKAYA (1969) listed Chara, the mosses Sphagnum, Drepanocladum and Fontinalis, and Equisetum, Ceratophyllum, Nymphaea, Nasturtium, Myriophyllum, Elodea, Potamogeton and Lemna, as well as Scirpus and Phragmites as important food plants of astacid crayfish in the former U.S.S.R. and MAGNUSON et al. (1975) proposed astacid crayfish for macrophyte control. The emergent sedges Carex and Scirpus were two of the four main categories in Astacus astacus in Swedish ponds (ABRAHAMSSON, 1966). A. astacus in Lake Steinfjorden, Norway, generally contained brownish, decaying macrophyte stems and rarely fresh green leaves (HESSEN and SKURDAL, 1986). RENZ and BREITHAUPT (2000) also found that dead leaves were the preferred kind of plant material taken by Austropotamobius torrentium. In feeding tests, Procambarus clarkii showed a preference for decaying over fresh macrophytes (ILHEU and BERNARDO, 1995). Elsewhere, stomach contents of marron (Cherax tenuimanus) suggest that they predominantly utilise amorphous, fine-grained organic material (O'BRIEN, 1998; O'BRIEN and DAVIES, 2002). These authors state that parastacids and astacids farm the detrital food chain and that although living macrophytes and some animal matter have been detected in foreguts, they consider it unlikely that they provide a major component of their nutrient and energy requirements.

But are these plant components assimilated? ILHEU and BERNARDO (1995) found that microbially conditioned plant detritus was assimilated better than fresh macrophytes. WHITLEDGE and RABENI (1997) used stable isotopes to look at diel and seasonal variation in two species of Orconectes. They concluded that allochthonous detritus was the main carbon source over the year, but chironomid larvae occurred in high proportions of crayfish in each month. PARKYN and COLLIER (2002) also investigated food web components in Paranephrops. Survival was enhanced when crayfish were fed chironomid larvae in addition to leaf detritus. Stable isotopes indicated that leaf detritus from elm and fern was not assimilated into crayfish tissue, unlike the chironomids, which directly contributed to growth. Other authors have also noted that best growth and survival was obtained with animal protein (e.g. OLIVEIRA and FABIAO 1998) and zooplankton diets (VERHOEF, JONES and AUSTIN, 1998). MICKËNIENË and SYROKIENË (1997) found no cellulase activity or cellulase-degrading microflora in the guts of astacid crayfish, and suggest that crayfish are typical polyphages, the ratio of animal to plant food depending on seasons, conditions and the life cycle. They further suggest that Chara is eaten not for food but for its mineral content. 
Large populations of crayfish (such as occur(red) at White Lake and Lisheens stream) are known to have a considerable effect on the biota of their home area, directly through predation or indirectly (e.g. LORMAN and MAGNUSON, 1978; MOMOT, GOWING and JONES, 1978; WEBER and LODGE, 1990; MATTHEWS, REYNOLDS and KEATINGE, 1993; LODGE et al., 1994). Impacts may occur at many levels of the food web, and manifest themselves in changed community structure or lower biodiversity. Effects may be directly or indirectly via macrophytes (NYSTRÖM, 1999) or algae (NYSTRÖM, 2002), on lotic or lentic macroinvertebrates (e.g. MACAN, 1977; HANSON, CHAMBERS and PREPAS, 1990; CHARLEBOIS and LAMBERTI, 1996; NYSTRÖM, BRONMARK and GRANELI, 1996). This may be one reason why flatworms and lymnaeid molluscs were so uncommon in White Lake during the study, while abundant in a similar Irish midlands lake, Pallas Lake, Co. Offaly, which lost its crayfish populations some three decades earlier (MORIARTY, 1973). Further evidence of crayfish impact on White Lake Chara is presented by REYNOLDS et al. (2000). DEAN (1969) reported a strong negative correlation between crayfish numbers and density of macrophytes in different parts of a lake in New Mexico, while LODGE and LORMAN (1987) noted declines in macrophyte diversity and biomass. In a lagoon enclosure study, red swamp crayfish (Procambarus clarkii) reduced macrophyte biomass by some $50 \%$ and invertebrates by $86 \%$. Chara suffered major loss, as did the associated gastropods (ILHEU, GUILHERME and BERNARDO, 2002). In streams also, USIO (2002) found that a New Zealand crayfish affected invertebrate distribution, being negatively associated with a large predatory caddisfly and positively associated with mayfly and stonefly nymphs following relaxed predation in a trophic cascade.

What makes a stream and a lake crayfish feed so differently? We conclude that it relates to the different opportunities presented: lakes have more equable temperatures, with less diurnal variation, so ecdysis and growth are regular and predictable. Food is also predictable, zooplankton and benthic microcrustaceans peak in summer providing optimal food for sub-yearlings. Aquatic plants are available fresh up to midsummer, thereafter senescing and more attractive as food. Terrestrial allochthonous food is perhaps less available, but littoral-dwelling crayfish will encounter what there is.

By contrast, stream habitats are more stochastic, with temperature fluctuations and unpredictable flooding in spring, which may wash food out of shallow riffles. Animal matter is always important. Insect larvae in non-catastrophic drift may provide supplementary food to crayfish in quieter stretches and under banks. Terrestrial allochthonous plant material is important, particularly in the second half of the year. Despite these habitat induced differences, we conclude that the diet of Austropotamobius pallipes is apparently rather similar to that described for $A$. torrentium, with an emphasis on carnivory and a low preference for fresh plant material.

\section{ACKNOWLEDGEMENTS}

We would like to thank our colleagues in the National Parks and Wildlife Service and in the Department of Zoology, Trinity College, Dublin, (in particular Andréanne DEMERS, Roger BYRNE, Jane WOODLOCK, Martyn LINNIE, Peter STAFFORD and Richard HOLLINSHEAD) for many years of help and fruitful collaboration in crayfish study. JDR is also grateful to colleagues in CRAYNET for stimulating interactions, and especially to Dr Catherine Souty-Grosset for her kind sponsorship of him as Professeur Invité at the Laboratoire de Génétique et Biologie des populations de Crustacés, University of Poitiers.

\section{REFERENCES}

ABRAHAMSSON S., 1966. Dynamics of an isolated population of the crayfish Astacus astacus Linné. Oikos, 17, 96-107. 
ANDRÉ M., 1960. Les écrevisses françaises. Editions Paul Chevalier, Paris.

CHARLEBOIS P.M., LAMBERTI G.A., 1996. Invading crayfish of a Michigan stream: direct and indirect effects on periphyton and macroinvertebrates. Journal of the North American Benthological Society, 15, 551-563.

DEAN J.L., 1969. Biology of the crayfish Orconectes causeyi and its use for control of aquatic weeds in trout lakes. US Bureau Sport Fish. Wildl. Tech. Pap. No. 25. 15 p.

GAEVSKAYA N.S., 1969. The role of higher aquatic plants in the nutrition of the animals of freshwater basins. National lending Library for Science and Technology, Boston Spa.

GOUIN N., GRANDJEAN F., PAIN S., SOUTY-GROSSET C., REYNOLDS J., 2003. Origin and colonization history of the white-clawed crayfish, Austropotamobius pallipes, in Ireland. Heredity, 91, 70-77.

GUAM R.-Z., WILES P.R., 1997. Ecological impact of introduced crayfish on benthic fishes in a British lowland river. Conservation Biology, 11, 641-647.

HANSON J.M., CHAMBERS P.A., PREPAS E.E., 1990. Selective foraging by the crayfish Orconectes virilis and its impact on macroinvertebrates. Freshwater Biology, 24, 69-80.

HESSEN D.G., SKURDAL J., 1986. Feeding of the crayfish Astacus astacus in Lake Steinsfjorden, SE Norway. Freshwater Crayfish, 6, 187-193.

HESSEN D.G., SKURDAL J., 1988. Food consumption, turnover rates and assimilation in the noble crayfish (Astacus astacus). Freshwater Crayfish, 7, 309-317.

HOLDICH D.M., ROGERS W.D., 1997. The white-clawed crayfish, Austropotamobius pallipes, in Great Britain and Ireland with particular reference to its conservation in Great Britain. Bull. Fr. Pêche. Piscic., 347, 597-616.

HUXLEY T.H., 1880. The crayfish: an introduction to the study of Zoology. Kegan Paul, London.

HYNES H.B.N., 1959. The food of freshwater sticklebacks Gasterosteus aculeatus and Pygosteus pungitius, with a review of methods used in the study of the food of fishes. J. Anim. Ecol., 19, 36-58.

ILHEU M., BERNARDO M., 1993. Experimental evaluation of food preferences of red swamp crayfish, Procambarus clarkii: vegetal versus animal. Freshwater Crayfish, 9, 359-364.

ILHEU M., BERNARDO M., 1995. Trophic ecology of red swamp crawfish Procambarus clarkii (Girard) - preferences and digestibility of plant foods. Freshwater Crayfish, 10, 132-139.

ILHEU M., GUILHERME P., BERNARDO J.M., 2002. Impact on the aquatic invertebrates and macrophyte communities by red swamp crayfish (Procambarus clarkii): an enclosure study in the south of Portugal. Freshwater Crayfish, 13, 609-610.

LODGE D.M., HILL A.M., 1994. Factors governing species composition, population size and productivity of cool-water crayfishes. Nordic Journal of Freshwater Research, 69, 111-136.

LODGE D.M., LORMAN J.G., 1987. Reductions in submersed macrophyte biomass and species richness by the crayfish Orconectes rusticus. Canadian J. Fish. Aquat. Sci., 44, 591-7.

LODGE D.M., KERSHNER M.W., ALOI J.E., COVICH A. 1994. Effects of an omnivorous crayfish (Orconectes rusticus) on a freshwater littoral food web. Ecology, 75, 12651281. 
LORMAN J.G., MAGNUSON J.J., 1978. The role of crayfishes in aquatic systems. Fisheries, 3, 8-10.

LUCEY J., McGARRIGLE M.L., 1987. The distribution of the freshwater crayfish in Ireland. Irish Fisheries Invest., 29A, 1-13.

MACAN T.T., 1977. The influence of predation on the composition of freshwater aquatic ecosystems. Biol. Rev., 52, 45-70.

MAGNUSON J.J., CAPELLI G.M., LORMAN J.G., STEIN R.A., 1975. Consideration of crayfish for macrophyte control. In: Brezonik, PL, and Fox JL (eds.) The proceedings of a symposium on water quality management through biological control. Rept. No. ENV 07-75-1, Univ. of Florida, Gainesville.

MASON J.C., 1975. Crayfish production in a small woodland stream. Freshwater Crayfish, 2, 449-480.

MATTHEWS M., REYNOLDS J.D., 1992. Ecological impact of crayfish plague in Ireland. Hydrobiologia, 234, 1-6.

MATTHEWS M., REYNOLDS J.D., KEATINGE M.J., 1993. Macrophyte reduction and benthic community alteration by the crayfish Austropotamobius pallipes (Lereboullet). Freshwater Crayfish, 9, 289-299.

MICKËNIENË L., SYROKIENË J., 1997. Microflora in the digestive tract of freshwater crayfish. Freshwater Crayfish, 11, 441-450.

MOMOT W.T., 1995. Redefining the role of crayfish in aquatic ecosystems. Reviews in Fisheries Science, 3, 33-63.

MOMOT W.T., GOWING H., JONES P.D., 1978. The dynamics of crayfish and their role in ecosystems. Amer. Midl. Nat., 99, 10-35.

MORIARTY C., 1973. A study of Austropotamobius pallipes in Ireland. Freshwater Crayfish, I, 57-67.

NYSTRÖM P., 1999. Ecological impact of introduced and native crayfish on freshwater communities: European perspectives. Pp.63-85 In: Crayfish in Europe, eds. F. GHERARDI, D. HOLDICH. Balkema, Rotterdam.

NYSTRÖM P., 2002. Ecology. Chapter 5, pp. 192-235, in Biology of Freshwater Crayfish, ed. D.M. HOLDICH. Blackwell Science.

NYSTROM P., BRONMARK M.W., GRANELI W.. 1996. Patterns in benthic food webs: a role for omnivorous crayfish? Freshwater Biology, 36, 631-646.

O'BRIEN B.G., 1998. The natural diet of the freshwater crayfish Cherax tenuimanus (Smith 1912) (Decapoda: Parastacidae) as determined by gut content analysis. Freshwater Crayfish, 10, 151-162.

O'BRIEN B.G., DAVIES P.M., 2002. The structure of marron (Cherax tenuimanus) food webs in commercial ponds: results from multiple stable isotope analyses. Freshwater Crayfish, 13, 155-163.

O'KEEFFE C., 1986. The ecology of two populations of the freshwater crayfish Austropotamobius pallipes (Lereboullet) in Ireland. PhD Thesis, University of Dublin.

OLIVEIRA J., FABIAO A. 1998. Growth responses of juvenile red swamp crayfish, Procambarus clarkii Girard, to several diets under controlled conditions. Aquaculture Research, 29, 123-129.

PARKYN S.M., COLLIER K.J., 2002. Differentiating the effects of diet and temperature on juvenile crayfish (Paranephrops planifrons) growth: leaf detritus versus invertebrate 
food sources at two diurnally varying temperatures. Freshwater Crayfish, 13, 371382.

RENZ M., BREITHAUPT T., 2000. Habitat use of the crayfish Austropotamobius torrentium in small brooks and in Lake Constance, Southern Germany. Bull. Fr. Pêche Piscic. 356, 139-153.

REYNOLDS J.D., 1979. Crayfish ecology in Ireland. Freshwater Crayfish, 4, 215-220.

REYNOLDS J.D., 1988. Crayfish extinctions and crayfish plague in Ireland. Biological Conservation, 45, 279-285.

REYNOLDS J.D., 1997. The present status of freshwater crayfish in Ireland. Bull. Fr. Pêche Piscic., 347, 693-700.

REYNOLDS J.D., DONOHUE R., 2001. Crayfish predation experiments on the introduced zebra mussel, Dreissena polymorpha, in Ireland, and their potential for biocontrol. Bull. Fr. Pêche Piscic., 361, 669-682.

REYNOLDS J.D., DEMERS A., MARNELL F., 2002. Managing an abundant crayfish resource for conservation - Austropotamobius pallipes in Ireland. Bull. Fr. Pêche Piscic., 367, 823-832.

REYNOLDS J.D., SOUTY-GROSSET C., GOUIN N., DEVANEY S., GRANDJEAN F., 2000. Experimental restocking of native crayfish in White Lake, Co. Westmeath, Ireland. Pp 123-130 In: Crayfish Conference Leeds, eds. D. ROGERS, J. BRICKLAND. Nature Conservancy.

REYNOLDS J.D., GOUIN N., PAIN S., GRANDJEAN F., DEMERS A., SOUTY-GROSSET C., 2002. Irish crayfish populations: ecological survey and preliminary genetic findings. Freshwater Crayfish, 13, 584-594.

SAFFRAN K.A., BARTON D.R., 1993. Trophic ecology of Orconectes propinquus in Georgian Bay (Ontario, Canada). Freshwater Crayfish, 9, 350-358.

TCHERKASHINA N.Y., 1977. Survival, growth and feeding dynamics of juvenile crayfish (Astacus leptodactylus cubanicus) in ponds and the River Don. Freshwater Crayfish, 3, 95-100.

THOMAS W.J., 1977. The biting edges of the chelae and periopods of Austropotamobius pallipes. Experientia, 33, 1037-1038.

THOMAS W.J., 1979. Aspects of crayfish biology. Freshwater Crayfish, 4, 115-122.

USIO N., 2002. Do crayfish affect invertebrate distribution in a headwater stream? Freshwater Crayfish, 13, 396-404.

VERHOEF G.D., JONES P.L., AUSTIN C.M., 1998. A comparison of natural and artificial diets for juveniles of the Australian freshwater crayfish Cherax destructor. Journal of the World Aquaculture Society, 29, 243-248.

WARNER G.F., 1997. Factors affecting the selection of pond snail prey by signal crayfish. Freshwater Crayfish, 10, 194-303.

WEBER L.M., LODGE D.M., 1990. Periphytic food and predatory crayfish: relative roles in determining snail distribution. Oecologia, 82, 33-39.

WESTMAN K., SARKKA J., PURSIAINEN M., SUMARI O., 1986. Population structure and gut contents of the crayfish Astacus astacus in two Finnish rivers. Freshwater Crayfish, 6, 166-177.

WHITLEDGE G.M., RABENI, C.F., 1997. Diel and seasonal variation in the food habits of crayfishes in a Missouri Ozark stream. Freshwater Crayfish, 11, 155-169. 